\title{
FAKTOR - FAKTOR YANG BERHUBUNGAN DENGAN PEMERIKSAAN CA SERVIK MENGGUNAKAN METODE VISUAL ASAM ASETAT (IVA)
}

\author{
Nurhimah Apriyanti ${ }^{1}$, Vida Wira Utami ${ }^{2}$, Yuli Yantina ${ }^{3}$, Dessy Hermawan ${ }^{4}$ \\ ${ }^{1}$ Program Studi DIV Kebidanan Fakultas Kedokteran Universitas Malahayati \\ Email:nurhimahapriyanti@gmail.com \\ 2Dosen Program Studi DIV Kebidanan UniversitasMalahayati \\ Email vida_harmawan@yahoo.com \\ ${ }^{3}$ Dosen Program Studi DIV Kebidanan UniversitasMalahayati \\ Emailyantina.yuli@yahoo.co.id \\ ${ }^{4}$ LPMI Universitas Malahayati \\ Email hermawan.dessy@gmail.com
}

\begin{abstract}
BackgraoundThe target of achieving IVA in Lampung with a target of $60 \%$ in 2017 , with the number of WUS in the Puseksmas Hajimena Working Area numbering 3882 with WUS who came to do the examination totaling $635(16.35 \%)$. In 2018 the target coverage of IVA examination was $70 \%$, with the number of WUS 4738 with the number of WUS carrying out IVA examinations totaling 427 (9.02\%).

The purpose of the study was to find out the Factors Associated with Examination of CaServic Using Visual Acetate (Iva) Method in the Work Area of Hajimena Health Center, Natar District, South Lampung Regency in2019.

Method Quantitative research with cross sectional research types. The research variables were knowledge, husband's support and the role of health workers with CaServik examination using the Visual Acetic Acid (IVA) Method. The population is for women of childbearing age who have a number of 96 people, taking samples by proporsional random sampling. Research in the working area of Hajimena Community Health Center in May-June 2019.Using primary data.Data collection using a questionnaire. Data analysis was univariate and bivariate (chisquare).

The results of the study revealed that respondents who did not carry out IVA examination were 66 $(80.5 \%)$. Poor knowledge is $65(79.3 \%)$. Respondents had no husband support as many as $51(62.2 \%)$. Respondents were supported by officers about 46 (56.1\%) IVA examinations.

There is a relationship between knowledge with theexamination of Servic $\mathrm{Ca}$ Using the Visual Acetic Acid (IVA) Method(p-value $=0.011$ and OR $7.438(95 \% \mathrm{Cl} 1.566-35,332))$. There is a husband's support relationship ( $p$-value $=0.003$ and OR $6.900(95 \% \mathrm{Cl}$ 1.982-24.021)).

Conclusion There is a relationship between the role of health workers ( $p$-value $=0.011$ and OR 7.438 (95\% Cl 1.566- 35,332)).

Suggestions further increase counseling on WUS about cervicalcancer.
\end{abstract}

Keywords: cervical cancer, knowledge, husband's support, health worker support, IVA

\section{ABSTRAK}

Latar belakang Target pencapaian IVA di Lampung dengan Target $60 \%$ padatahun 2017, dengan jumlah WUS di Wilayah Kerja Puseksmas Hajimena berjumlah 3882 dengan WUS yang datanguntuk melakukan pemeriksaan berjumlah 635 (16,35\%). Padatahun 2018 target cakupan pemeriksaan IVA 70\%, dengan jumlah WUS 4738 dengan jumlah WUS yang melakukan pemeriksaan IVA berjumlah $427(9,02 \%)$.

Tujuan penelitian diketahuiFaktor - Faktor Yang Berhubungan Dengan Pemeriksaan Ca Servik Menggunakan Metode Visual AsamAsetat (Iva) Di Wilayah Kerja Puskesmas Hajimena Kecamatan Natar Kabupten Lampung Selatan Tahun2019.

Metode Penelitian kuantitatif dengan jenis penelitian cros sectional. Variabel penelitian pengetahuan, dukungan suami dan peran petugas kesehatan dengan pemeriksaan CaServik menggunakan Metode Visual AsamAsetat (IVA). Populasi kepada wanita usia subur yang memiliki pasangan berjumlah 96 orang, pengambilan sampel secara proporsional random sampling. Penelitian di wilayah kerja Puskesmas Hajimena bulan Mei-Juni 2019. Menggunakan data primer. Pengumpulan data menggunakan kuesioner. Analisis data secara univariat dan 
bivariat (chisquare).

Hasil penelitian diketahui bahwa responden yang tidak melakukan pemeriksaan IVA sebanyak 66 $(80,5 \%)$. Pengetahuan kurang baik sebanyak $65(79,3 \%)$. Responden tidak ada dukungan suami sebanyak 51 $(62,2 \%)$. Responden ada dukungan petugas tentang pemeriksaan IVA sebanyak $46(56,1 \%)$.

Kesimpulan Ada hubungan pengetahuan dengan pemeriksaan CaServik Menggunakan Metode Visual Asam Asetat (IVA) ( $p$-value $=0,011$ dan OR 7,438 (Cl 95\% 1,566-35,332)). Ada hubungan dukungan suami ( $p$ value $=0,003$ dan OR $6,900(\mathrm{Cl} 95 \% 1,982-24,021))$. Ada hubungan peran petugas kesehatan $(p$-value $=0,011$ dan OR 7,438 (Cl 95\% 1,566-35,332)).

Saran lebih meningkatkan penyuluhan pada WUS tentang kanker serviks.

Kata kunci: kanker servik, pengetahuan, dukungan suami, dukungan petugas kesehatan, pemeriksaan IVA

\section{PENDAHULUAN}

Kanker serviks merupakan keganasan yang paling banyak ditemukan di berkembang begitu juga di Indonesia menduduki peringkat 1 . Umumnya kanker serviks sekitar $70 \%$ datang dengan kondisi stadium lanjut Kejadian kanker serviksdapat dicegah dengan deteksi dini lesi prakanker. Kegiatan deteksi dini kanker leher rahim dilakukan dengan metode Inspeksi Visual dengan Asam Asetat (IVA), pemeriksaan IVA bertujuan untuk menemukan lesi pra kanker leher rahim, sebelummenjadi kanker. Metode inspeksi visual lebih mudah, lebih sederhana dan lebih mampu laksana. Metode ini dapat dilakukan di semua tingkat pelayanan kesehatan oleh petugas kesehatan yang terlatih (Kemenkes,2015).

Kanker serviks merupakan kanker paling sering keempat pada wanita dengan perkiraan 530.000 kasus baru, yang mewakili $7,9 \%$ dari semua kanker wanita. Pada tahun 2015 sekitar 90\% kematian atau sebanyak 270.000 akibat kanker serviks terjadi di negara berpenghasilan rendah dan menengah (World Health Organization, 2017).

Penyakit Kanker Serviks merupakan penyakit kanker dengan prevalensi tertinggi di Indonesia pada tahun 2013, yaitu Kanker Serviks sebesar 0,8\%Provinsi Kepulauan Riau, Provinsi Maluku Utara dan Provinsi D.I. Yogyakarta memiliki prevalensi Kanker Serviks tertinggi yaitu sebesar 1,5\%. Berdasarkan estimasi jumlah penderita Kanker Serviks terbanyak terdapat pada Provinsi Jawa Timur dan Provinsi Jawa Tengah, sedangkan di Provinsi Lampung sebesar 0,2\% atau sebanyak 765orang(Kemenkes, 2015).

Tahun 2016 dari 1.739 jumlah wanita PUS yang dicurigai Kanker Serviks, provinsi Lampung merupakan urutan ketiga tertinggi dengan jumlah 227 kasus setelah DKI Jakarta (269 kasus) dan Bali sebanyak 254 kasus (Kemenkes, 2017).

Berdasarkan laporan dari 25 rumah sakit dengan jumlah penderita kanker berkunjung dan dirawat di rumah sakit di Provinsi Lampung selama tahun 2014 mencapai 283 penderita dan pencapaian pemeriksaan deteksi dini kanker leher rahim di tahun 2014 sebanyak 7.920 orang. Provinsi Lampung tahun 2015, dari 8.705 wanita Usia Subur (WUS) yang melakukan pemeriksaan IVA sebanyak 306 WUS dengan IVA positif dimana kasus tertinggi di Kabupaten Lampung Selatan dari 2.900 wanita yang melakukan pemeriksaan IVA sebanyak 57 orang dinyatakan positif atau sebesar $(1,96 \%)$ dan terendah di Kabupaten Lampung Barat dan Pesisir Barat dengan kejadian 0. Sedangkan Kabupaten Lampung Selatan tercatat memiliki target Wus 11.130, dari target tersebut tercatat $480(4,31 \%)$ wanita yang melakukan pemeriksaan IVA, sebanyak $19(3,95 \%)$ wanita dengan IVA positif. Hal ini terlihat bahwa belum terpenuhi target pemeriksaan IVA di Kabupaten Lampung Selatan (Dinas Kesehatan Provinsi Lampung, 2016). Tahun 2016, dari 1.210.947 perempuan usia 30-49tahun, sebanyak $28.612(2,36 \%)$ perempuan yang melakukan pemeriksaan IVA, Kabupaten tertinggi ada di Kabupaten Lampung Tengah sebanyak $11.459(8,02)$ orang dan terendah di lampung Selatan sebanyak 171 (0,09\%) (DinasKesehatan provinsi Lampung,2016)

Tes IVA (Inspeksi Visual dengan Asam Asetat) merupakan salah satu cara untuk deteksi dini penyakit kanker serviks atau kanker mulut rahim. Dengan metode inspeksi visual yang lebih mudah, lebih sederhana, lebih mampu dilaksanakan maka skrining dapat dilakukan dengan cakupan lebih luas, diharapkan temuan kanker serviks dini akan bisa lebih banyak. Jumlah WUS yang diperiksa sebanyak 14.359 orang (10,9\%). Puskesmas yang mencapai target adalah puskesmas ketapang dengan jumlah pemeriksaan sebanyak 1.824 orang $20,04 \%$ ) dengan hasil pemeriksaan positif sebanyak 282 orang. Puskesmas yang paling sedikit melakukan pemeriksaan IVA CBE adalah puskesmas merbau mataram sebanyak 187 orang (5,5\%) (Profil Dinas Kesehatan Kabupaten Lampung Selatan,2017). 
Pada tahun 2016 di Kabupaten Lampung Selatan di semua Puskesmas sudah melakukan pemeriksaan IVA sebanyak 13\% (11.692 orang). Sasaran wanita usia 30 - 50 tahun sebanyak 140.689 orang dengan target capaian tahun 2016 adalah $20 \%$ (28.137 orang), dari pemeriksaan tersebut dilaporkan yang menderita IVA positif sebanyak 2,41\% (282 orang) dan 0,93\%(109 orang) mengidap tumor atau benjolan. Persentase pemeriksaan IVA tertinggi ada di Puskesmas RI Ketapang sebanyak $42 \%$ (1.824 orang) dan yang terendah di Puskesmas Merbau Mataram sebanyak 2\% (75 orang) sedangkan di Puskesms Hajimena sebesar $7 \%$ (263) orang.Target pencapaian IVA di Lampung dengan Target $60 \%$ pada tahun 2017, dengan jumlah WUS di Wilayah Kerja Puseksmas Hajimena berjumlah 3882 dengan WUS yang datang untuk melakukan pemeriksaan berjumlah 635 (16,35\%). Pada tahun 2018 target cakupan pemeriksaan IVA $70 \%$, dengan jumlah WUS 4738 dengan jumlah WUS yang melakukan pemeriksaan IVA berjumlah 427 (9,02\%) (Profil Puskesmas Hajimena, 2018).

Tes Inspeksi Visual Asam Asetat (Tes IVA) adalah suatu metode skrining kanker serviks dengan menggunakan larutan asam asetat 3-5\% pada serviks dan melihat perubahan warna yang terjadi setelah dilakukan olesan yang bertujuan untuk melihat adanya sel serviks yang mengalami displasia.(Kemenkes, 2013). Penelitian membuktikan bahwa tes IVA memiliki tingkat sensitivitas dan spesifisitas yang cukup tinggi untuk digunakan sebagai metode penapisan lesi prakanker.

Menurut Notoadmodjo, 2012 Keikutsertaan pemeriksaan IVA suatu bentuk perilaku yang disebabkan oleh berbagai hal antara lain karena faktor predisposisi (pengetahuan, sikap, dan lainlain), pemungkin dan penguat. Selain itu, terdapat beberapa faktor lain (tingkat pendidikan, sikap, faktor risiko kanker serviks, akses informasi, keterjangkauan jarak, kepesertaan jaminan kesehatan, dukungan petugas kesehatan, dukungan keluarga, dan peran kader kesehatan) yang dapat mempengaruhi kunjunganIVA.

Hasil penelitian ini sesuai dengan penelitian Damailia (2015) dalam Nordianti (2018), bahwa ada hubungan antara dukungan petugas kesehatan dengan deteksi dini kanker serviks melalui metode pap smear, hal ini dapat ditunjukkan dari proporsi WUS yang pernah melakukan deteksi dini kanker serviks melalui metode pap smear seluruhnya ditemukan pada PUS yang mendapat dukungan dari petugas kesehatan.

Faktor lain yang mempengaruhi seorang wanita melakukan pencegahan Kanker Serviks diantaranya adalah dukungan dari suami yang dapat menumbuhkan dan memberikan motivasi untuk melakukan pemeriksaan deteksi dini Kanker Serviks . Suami yang mempunyai pemahaman yang baik dapat memberikan penjelasan dan dukungannya kepada istri untuk melaksanakan perilaku sehat (Setiadi, 2008).

Hasil penelitian Setyanti (2017) Dukungan suami dalam Kategori rendah sebanyak 1 responden $(1,8 \%)$, sedang 29 responden $(52,7 \%)$ dan tinggi 25 responden $(45,5 \%)$. Perilaku WUS melakukan IVA kategori negatif sebanyak 8 responden $(14,5 \%)$ dan perilaku positif sebanyak 47 responden $(85,5 \%)$. Hasil uji Chi Square p-value $0,015<0,05$.

Berdasarkan hasil prasurvey yang dilakukan dengan wawancara tidak terstruktur kepada 20 wanita usia subur yang ada di wilayah Puskesmas Hajimena Lampung Selatan, diketahui bahwa sebanyak $15(75 \%)$ wanita belum pernah melakukan pemeriksaan IVA. Dari 15 orang yang belum pernah melakukan pemeriksaan tersebut, diketahui berbagai alasan penyebab tidak melakukan pemeriksaan, sebanyak 11 (73,3\%) wanita mengatakan bahwa pemeriksaan IVA hanya untuk wanita yang sudah berumur saja atau usia di atas 50 tahun, dari 15 wanita yang tidak pernah melakukan pemeriksaan IVA tersebut diketahui sebanyak $8(53,3 \%)$, wanita mengatakan belum pernah petugas kesehatan memberitahu untuk melakukan pemeriksaan IVA maupun memberikan informasi terkait penyakit Kanker Serviks, dari 15 wanita yang tidak pernah melakukan pemeriksaan IVA tersebut diketahui sebanyak $7 \quad(46,7 \%)$ responden mengungkapkan belum ada biaya untuk melakukan pemeriksaan IVA, dari 15 wanita yang tidak pernah melakukan pemeriksaan IVA tersebut diketahui sebanyak $9 \quad(60,0 \%)$ responden mengatakan tidak mendapatkan dukungan suami untuk melakukan pemeriksaanIVA.

Berdasarkan hasil telaah dokumen Puskesmas Hajimena dari angka sasaran yang ditargetkan oleh Dinas Kesehatan Kabupaten Lampung Selatanadalah sebesar 2.007 Wanita Usia Subur yang aktif dalam kegiatan seksual diharapkan datang untuk memeriksa IVA ternyata sampai tahun 2018 capaian di puskesmas Hajimena baru $7 \%$ (140 WUS) yang memeriksa IVA. Jumlah tersebut masih jauh di bawah angka yang ditargetkan oleh Dinas Kesehatan Kabupaten LampungSelatan.

Berdasarkan paparan di atas, maka penulis tertarik untuk meneliti tentangFaktor Faktor Yang Berhubungan Dengan Pemeriksaan 
Ca Servik Menggunakan Metode Visual Asam Asetat (Iva) Di Wilayah Kerja Puskesmas Hajimena Kecamatan Natar Kabupten Lampung Selatan Tahun2019.

\section{METODE PENELITIAN}

Jenis penelitian yang digunakan dalam penelitian ini adalah penelitian kuantitatif, Desain atau rancangan penelitian analitik dengan pendekatan Cross Sectional

Populasi pada penelitian ini adalah seluruh wanita usia subur yang ada di Wilayah Kerja Puskesmas Hajimena Kecamatan Natar, dengan jumlah wanita pasangan usia subur sebanyak 4738 orang, dengan jumlah WUS yang melakukan pemeriksaan IVAsebanyak 427 WUS. Sampel dalam penelitian ini menggunakan metode proporsional random sampling sebanyak 82 responden

\section{HASIL PENELITIAN \\ Analisis Univariat}

Berdasarkan tabel 1 dapat dilihat bahwa responden yang melakukan pemeriksaan IVA sebanyak $16(19,5 \%)$ responden lebih sedikit jika dibandingkan dengan responden yang tidak melakukan pemeriksaan IVA yaitu sebanyak 66 $(80,5 \%)$ responden.

Tabel 1 Distribusi Frekuensi wanita usia subur yang melakukan pemeriksaan IVA di wilayah kerja Puskesmas Hajimena Kecamatan Natar Kabupten Lampung Selatan tahun 2019

\begin{tabular}{cccc}
\hline Variabel & Kategori & Jumlah & $\%$ \\
\hline \multirow{2}{*}{ Pemeriksaan IVA } & Melakukan pemeriksaan IVA & 16 & 19,5 \\
& Tidak melakukan pemeriksaan IVA & 66 & 80,5 \\
\hline \multicolumn{2}{c}{ Total } & 82 & 100,0 \\
\hline
\end{tabular}

Tabel 2 Distribusi Frekuensi Pengetahuan Dengan Pemeriksaan Ca Servik Menggunakan Metode Visual Asam Asetat (IVA) Di Wilayah Kerja Puskesmas Hajimena Kecamatan Natar Kabupten Lampung Selatan Tahun 2019

\begin{tabular}{|c|c|c|c|}
\hline Variabel & Kategori & Jumlah & $\%$ \\
\hline \multirow{2}{*}{ Pengetahuan } & Baik & 17 & 20,7 \\
\hline & Kurang baik & 65 & 79,3 \\
\hline & Total & 82 & 100,0 \\
\hline
\end{tabular}

Berdasarkan tabel 2 pengetahuan baik sebanyak $17(20,7 \%)$ responden lebih banyak jika dibandingkan dengan pengetahuan responden yang kurang baik yaitu sebanyak $65(79,3 \%)$ responden.

Tabel 3 Distribusi Frekuensi Dukungan Suami Dengan Pemeriksaan Ca Servik Menggunakan Metode Visual Asam Asetat (IVA) Di Wilayah Kerja Puskesmas Hajimena Kecamatan Natar Kabupten Lampung Selatan Tahun 2019

\begin{tabular}{llcc}
\hline \multicolumn{1}{c}{ Variabel } & Kategori & Jumlah & $\%$ \\
\hline Dukungan & Ada dukungan & 31 & 37,8 \\
Suami & Tidak ada dukungan & 51 & 62,2 \\
\hline \multicolumn{2}{c}{ Total } & 82 & 100,0 \\
\hline
\end{tabular}

Berdasarkan tabel 3 responden yang tidak ada dukungan suami sebanyak 31 $(37,8 \%)$ responden lebih banyak jika dibandingkan dengan responden yang ada dukungan suami yaitu sebanyak $51(62,2 \%)$ responden.
Berdasarkan tabel 4 responden yang mengatakan ada dukungan petugas tentang pemeriksaan IVA sebanyak $46(56,1 \%)$ responden lebih banyak jika dibandingkan dengan responden yang mengatakan tidak ada dukungan petugas kesehatan yaitu sebanyak $36(43,9 \%)$ responden. 
Tabel 4 Distribusi Frekuensi Peran Petugas Kesehatan Dengan Pemeriksaan Ca Servik Menggunakan Metode Visual Asam Asetat (IVA) Di Wilayah Kerja Puskesmas Hajimena Kecamatan Natar Kabupten Lampung Selatan Tahun 2019

\begin{tabular}{llcc}
\hline \multicolumn{1}{c}{ Variabel } & Kategori & Jumlah & $\%$ \\
\hline Peran petugas & Ada dukungan & 46 & 56,1 \\
kesehatan & Tidak ada dukungan & 36 & 43,9 \\
\hline & Total & 82 & 100,0 \\
\hline
\end{tabular}

\section{Analisis Bivariat}

Tabel 5 Hubungan Pengetahuan BerhubunganDengan Pemeriksaan Ca Servik Menggunakan Metode Visual Asam Asetat (IVA) Di Wilayah Kerja Puskesmas Hajimena Kecamatan Natar Kabupten Lampung Selatan Tahun 2019

\begin{tabular}{|c|c|c|c|c|c|c|c|c|}
\hline \multirow[t]{2}{*}{ Pengetahuan } & \multicolumn{2}{|c|}{$\begin{array}{c}\text { Melakukan } \\
\text { pemeriksaan IVA }\end{array}$} & \multicolumn{2}{|c|}{$\begin{array}{l}\text { Tidak Melakukan } \\
\text { pemeriksaan IVA }\end{array}$} & \multirow[t]{2}{*}{ Total } & \multirow[t]{2}{*}{$\%$} & \multirow[t]{2}{*}{$p$-valu e } & \multirow[t]{2}{*}{ OR 95\% Cl } \\
\hline & $\mathrm{n}$ & $\%$ & $\mathrm{n}$ & $\%$ & & & & \\
\hline Baik & 7 & 41,2 & 10 & 58,8 & 17 & 100 & 020 & 4,356 \\
\hline Kurang baik & 9 & 13,8 & 56 & 86,2 & 65 & 100 & $0,0<v$ & $(1,318-4,391)$ \\
\hline Total & 16 & 19,5 & 66 & 80,5 & 82 & 100 & & \\
\hline
\end{tabular}

Berdasarkan tabel 5 dapat dilihat dari 17 responden dengan pengetahuan baik, sebanyak 7 $(41,2 \%)$ respondenmelakukan pemeriksaan IVA dan sebanyak $10 \quad(58,8 \%)$ respondentidak melakukan pemeriksaan IVA. Dari 65 responden dengan pengetahuan kurang baik, sebanyak 9 $(13,8 \%)$ responden melakukan pemeriksaan IVA dan sebanyak $56 \quad(86,2 \%)$ responden tidak melakukan pemeriksaan IVA.

Hasil uji statistik diperoleh $p$-value $=0,029$ yang berarti $p<\alpha=0,05$ (Ho ditolak dan $\mathrm{Ha}$ diterima), maka dapat disimpulkan hubungan pengetahuan berhubungan Dengan Pemeriksaan Ca Servik Menggunakan Metode Visual Asam Asetat (IVA) Di Wilayah Kerja Puskesmas Hajimena Kecamatan Natar Kabupten Lampung Selatan Tahun 2019, dengan nilai OR 4,365(Cl 95\% 1,318-14,391)berarti responden dengan pengetahuan yang baikmemiliki peluang 4,0kali lebih besar untuk melakukan pemeriksaan IVA jika dibandingkan dengan responden yang memiliki pengetahuan kurang baik.

Tabel 6 Hubungan Peran Petugas Kesehatan Dengan Pemeriksaan Ca Servik Menggunakan Metode Visual Asam Asetat (Iva) Di Wilayah Kerja Puskesmas Hajimena Kecamatan Natar Kabupten Lampung Selatan Tahun 2019

\begin{tabular}{|c|c|c|c|c|c|c|c|c|}
\hline \multirow{2}{*}{$\begin{array}{c}\text { Peran petugas } \\
\text { kesehatan }\end{array}$} & \multicolumn{2}{|c|}{$\begin{array}{c}\text { Melakukan } \\
\text { pemeriksaan IVA }\end{array}$} & \multicolumn{2}{|c|}{$\begin{array}{l}\text { Tidak Melakukan } \\
\text { pemeriksaan IVA }\end{array}$} & \multirow[t]{2}{*}{ Total } & \multirow[t]{2}{*}{$\%$} & \multirow[t]{2}{*}{$p$-valu e } & \multirow[t]{2}{*}{ OR $95 \% \mathrm{Cl}$} \\
\hline & $\mathrm{n}$ & $\%$ & $\mathrm{n}$ & $\%$ & & & & \\
\hline Baik & 14 & 30,4 & 32 & 69,6 & 46 & 100 & & 7,438 \\
\hline Kurang baik & 2 & 5,6 & 34 & 94,4 & 36 & 100 & 0,011 & $(1,566-35,332)$ \\
\hline Total & 16 & 19,5 & 66 & 80,5 & 82 & 100 & & \\
\hline
\end{tabular}

Berdasarkan tabel 6 dapat dilihat dari 46responden mengatakan positif sebanyak 14 $(30,4 \%)$ responden melakukan pemeriksaan IVA dan sebanyak $32(69,6 \%)$ responden tidak melakukan pemeriksaan IVA. Dari 36 responden mengatakan negatif, sebanyak $2(5,6 \%)$ responden melakukan pemeriksaan IVA dan sebanyak 34 $(94,4 \%)$ responden tidak melakukan pemeriksaan IVA.
Hasil uji statistik diperoleh $p$-value $=0,011$ yang berarti $p<a=0,05(\mathrm{Ho}$ ditolak dan $\mathrm{Ha}$ diterima), maka dapat disimpulkan bahwa ada hubungan peran petugas kesehatan berhubunganDengan Pemeriksaan $\mathrm{Ca}$ Servik Menggunakan Metode Visual Asam Asetat (Iva) Di Wilayah Kerja Puskesmas Hajimena Kecamatan Natar Kabupten Lampung Selatan Tahun 2019, dengan nilai $\mathrm{OR} \quad 7,438 \quad(\mathrm{Cl} \quad 95 \%$ 1,566- 
35,332)berarti responden dengan dukungan peran petugas kesehatan memiliki peluang 7 kali lebih besar untuk melakukan pemeriksaan IVA jika dibandingkan dengan responden yang tidakada dukungan peran petugas.

\section{Tabel 7 Hubungan dukungan suami Dengan Pemeriksaan Ca Servik Menggunakan Metode Visual Asam Asetat (IVA) Di Wilayah Kerja Puskesmas Hajimena Kecamatan Natar Kabupten Lampung Selatan Tahun 2019}

\begin{tabular}{|c|c|c|c|c|c|c|c|c|}
\hline \multirow{2}{*}{$\begin{array}{l}\text { Dukungan } \\
\text { Suami }\end{array}$} & \multicolumn{2}{|c|}{$\begin{array}{c}\text { Melakukan } \\
\text { pemeriksaan IVA }\end{array}$} & \multicolumn{2}{|c|}{$\begin{array}{l}\text { Tidak Melakukan } \\
\text { pemeriksaan IVA }\end{array}$} & \multirow[t]{2}{*}{ Total } & \multirow[t]{2}{*}{$\%$} & \multirow[t]{2}{*}{$p$-value } & \multirow[t]{2}{*}{ OR 95\% Cl } \\
\hline & $n$ & $\%$ & $n$ & $\%$ & & & & \\
\hline \multirow{2}{*}{$\begin{array}{l}\text { Ada Dukungan } \\
\text { Tidak Ada } \\
\text { Dukungan } \\
\end{array}$} & 12 & 37,5 & 20 & 62,5 & 32 & 100 & \multirow[b]{2}{*}{0,003} & \multirow{2}{*}{$\begin{array}{c}6,900 \\
(1,982-24,021)\end{array}$} \\
\hline & 4 & 8,0 & 46 & 92,0 & 50 & 100 & & \\
\hline Total & 16 & 19,5 & 66 & 80,5 & 82 & 100 & & \\
\hline
\end{tabular}

Berdasarkan tabel 7 dapat dilihat dari 32responden positf, sebanyak $12(37,5 \%)$ responden melakukan pemeriksaan IVA dan sebanyak $20(62,5 \%)$ responden tidak melakukan pemeriksaan IVA. Dari 50 responden negatif, sebanyak $4 \quad(8,0 \%)$ responden melakukan pemeriksaan IVA dan sebanyak 46 (92,0\%) responden tidak melakukan pemeriksaan IVA.

Hasil uji statistik diperoleh $p$-value $=0,003$ yang berarti $p<a=0,05(\mathrm{Ho}$ ditolak dan $\mathrm{Ha}$ diterima), maka dapat disimpulkan bahwa ada hubungan dukungan suami berhubungan dengan Pemeriksaan Ca Servik Menggunakan Metode Visual Asam Asetat (Iva) Di Wilayah Kerja Puskesmas Hajimena Kecamatan Natar Kabupten Lampung Selatan Tahun 2019, dengan nilai OR 6,900(Cl 95\% 1,982-24,021) berarti responden ada dukungan suami memiliki peluang 6,9 kali lebih besar untuk melakukan pemeriksaan IVA jika dibandingkan dengan responden yang tidak ada dukungan suami.

\section{PEMBAHASAN}

\section{Analisa univariat}

\section{Pemeriksaan IVA}

Berdasarkan hasil penelitian dapat dilihat responden yang melakukan pemeriksaan IVA sebanyak $16(19,5 \%)$ responden lebih sedikit jika dibandingkan dengan responden yang tidak melakukan pemeriksaan IVA yaitu sebanyak 66 $(80,5 \%)$ responden.

Menurut Kemenkes (2010) hanya sebagian kecil dari perempuan yang menjalani dan mendapatkan hasil tes Pap juga menjalani evaluasi dan pengobatan yang semestinya bila ditemukan abnormalitas. Sebagai konsekuensinya, angka insidens kanker leher rahim tetap tinggi dan kebanyakan pasien datang pada stadium lanjut. Masalah yang berkembang akibat keterbatasan metode tes Pap inilah yang mendorong banyak penelitian untuk mencari metode alternatif skrining kanker leher rahim. Salah satu metode yang dianggap dapat dijadikan alternatif adalah metode inspeksi visual dengan asam asetat (IVA).

Penelitian yang dilakukan Sepa (2015) dengan judul Pengaruh Penyuluhan Kanker Serviks Terhadap Minat Pemeriksaan Pap Smear Pada Ibu Usia 20-60 Tahun Di Dusun Ngangkrik Triharjo Sleman Tahun 2015, diperoleh hasil sebelum penyuluhan minat pemeriksaan pap smear dalam kategori kurang, setelah penyuluhan diberikan minat dalam kategori baik. Ada beda pretestpostest $10,63(p=0,000)$.

Menurut pendapat peneliti manfaat dari pemeriksaan kanker serviks dengan metode IVA selain efektif karena dapat terdeteksi saat pemeriksaan juga tidak mengganggu ekonomi karena tidak dibebankan biaya selain itu pemeriksaan ini juga menurus peneliti dapat mengurangi morbiditas atau mortalitas dari penyakit kanker serviks, sehingga diharapkan adanya peningkatan pengetahuan dari masyarakat khususnya wanita usia subur untuk melakukan pemeriksaan IVA. Petugas kesehatan diharapkan dapat meningkatkan perannya secara aktif sehingga dapat meningkatkan cakupan pemeriksaan IVA.

Pengetahuan

Berdasarkan hasil penelitian diketahui pengetahuan kurang baik sebanyak 65 (79,3\%) respondenlebih banyak jika dibandingkan dengan pengetahuan responden yang baik yaitu sebanyak $17(20,7 \%)$ responden.

Pengetahuan (knowledge) merupakan hasil "tahu" dan ini terjadi setelah orang melakukan penginderaan terhadap suatu objek tertentu. Penginderaan terjadi melalui panca indera manusia. 
Sebagian besar pengetahuan manusia diperoleh melalui mata dan telinga. Pengetahuan atau kognitif merupakan domain yang sangat penting untuk terbentuknya tindakan seseorang. Karena itu dari pengalaman dan penelitian ternyata perilaku yang didasari oleh pengetahuan akan lebih langgeng daripada perilaku yang tidak didasari oleh pengetahuan (Notoatmojo, 2012).

Penelitian ini sejalan dengan penelitian yang dilakukan olehDewi (2013) denganhubungan tingkat pengetahuan dan sikap wanita usia subur (WUS) dengan pemeriksaan Inspeksi Visual Asam Asetat (IVA) Di Puskesmas Buleleng I. Hasil penelitian ini didapatkan dari 40 orang wanita usia subur di Puskesmas Buleleng I, sebagian besar (28 orang atau $70,0 \%$ mempunyai tingkat pengetahuan yang rendah tentang pemeriksaan IVA. Sedangkan wanita usia subur yang pengetahuannya tinggi sebanyak 12 orang atau $30,0 \%$.

Menurut pendapat peneliti pengetahuan merupakan hasil tahu yang terjadi setelah orang melakukan fungsi- fungsi pengindraan terhadap suatu kajian tertentu. Proses tersebut terjadi melalui penglihatan, pendengaran, penciuman, rasa dan perabaan. Pengetahuan yang kurang tentang suatu objek mengakibatkan kurangnya pemahaman tentang objek tersebut, sehingga bila seseorang tidak mengetahui mengenai kanker serviks dari maka akan mengakibatkan kurangnya pemahaman dalam pemanfaatan pemeriksaan IVA.

\section{Dukungan Suami}

Berdasarkan hasil penelitian diketahui responden yang tidak ada dukungan suami sebanyak $51(62,2 \%)$ responden lebih banyak jika dibandingkan dengan responden yang ada dukungan suami yaitu sebanyak $31 \quad(37,8 \%)$ responden.

Sejalan dengan teori menurut Friedman (2014) dukungan keluarga merupakan dukungan berupa informasi verbal, sasaran, bantuan yang nyata atau tingkah laku yang diberikan oleh orangorang yang akrab dengan subjek didalam lingkungan sosialnya atau yang berupa kehadiran dan hal yang dapat memberikan keuntungan emosional atau pengaruh pada tingkah laku penerimaannya.

Hasil penelitian yang dilakukan Kurniawati (2014) dengan judul Pengaruh Pengetahuan, Motivasi dan Dukungan Suami terhadap Perilaku Pemeriksaan IVA pada Wanita Usia Subur di Puskesmas Kedungrejo, diperoleh hasil penelitian menunjukkan bahwa mayoritas dukungan suami pada kategori baik yaitu sebanyak 35 orang
$(57,4 \%)$ dan responden dengan dukungan suami kurang sebanyak 26 orang $(42,6 \%)$.

Menurut pendapat peneliti dari hasil penelitian terdapat menunjukkan bahwa dukungan keluarga yang kurang karena kurangnya pengetahuan dari anggota keluarga lain mengenai pelayanan kesehatan yang dilakukan oleh keluarganya sendiri. Dari hasil penelitian diketahui bahwa pada item pernyataan suami ibu pernah mengatakan akan menemani ibu dalam pemeriksaan dengan metode IVA(Inspeksi VisualAsam Asetat) di Puskesmasmemiliki point terendah

\section{Dukungan Petugas Kesehatan}

Berdasarkan hasil penelitian diketahui responden yang mengatakan ada dukungan petugas tentang pemeriksaan IVA sebanyak 46 $(56,1 \%)$ responden lebih banyak jika dibandingkan dengan responden yang mengatakan tidak ada dukungan petugas kesehatan yaitu sebanyak 36 $(43,9 \%)$ responden.

Petugas kesehatan adalah seseorang yang bertanggung jawab dalam memberikan pelayanan kesehatan kepada individu, keluarga dan masyarakat. Petugas kesehatan berdasarkan pekerjaannya adalah tenaga medis, dan tenaga paramedis seperti tenaga keperawatan, tenaga kebidanan, tenaga penunjang medis dan lain sebagainya. Ada dua aspek mutu pelayanan kesehatan yang perlu dilakukan di puskesmas yaitu quality of care dan quality of service. Quality of care antara lain menyangkut keterampilan tehnis petugas kesehatan (dokter, bidan, perawat atau paramedis lain) dalam menegakkan diagnosis dan memberikan perawatan kepada pasien (Kemenkes, 2014).

Penelitian yang dilakukan olehMasturoh (2016) dengan judul Faktor Faktor yang Mempengaruhi Wanita Usia Subur (WUS) dalamMelakukan Deteksi Dini Kanker Serviks dengan Inspeksi Visual Asam Asetat(IVA) di Wilayah Kerja Puskesmas Bangetayu Kota Semarang. Hasil penelitian menunjukkan diperoleh data dari 99 responden yang mendapatkan dukungan kurang dari petugas kesehatan, sebanyak 96 responden $(97,0 \%)$ tidak melakukan pemeriksaan kanker serviks dan 3 responden $(3,0 \%)$ melakukan pemeriksaan kanker serviks dengan IVA. Sementara itu dari 64 responden yang mendapatkan dukungan dari petugas kesehatan sebanyak 56 responden $(87,5 \%)$ tidak melakukan pemeriksaan kanker serviks dan 8 responden (12,5\%) melakukan pemeriksaan kanker serviks dengan IVA 
Menurut pendapat peneliti peran petugas kesehatan untuk menyadari bahwa pemeriksaan IVA penting bagi Ibu/ WUS merupakan hal yang utama untuk meningkatkan derajat kesehatan dalam pendeteksian dini kanker servik, hal ini dapat menimbulkan perilaku positif ibu/WUS untuk melakukan pemeriksaan IVA .

\section{Analisa Bivariat}

Hubungan Pengetahuan Dengan Dengan Pemeriksaan $\mathrm{Ca}$ Servik Menggunakan Metode Visual Asam Asetat (IVA) Di Wilayah Kerja Puskesmas Hajimena Kecamatan Natar Kabupten Lampung Selatan Tahun 2019

Hasil uji statistik diperoleh $p$-value $=$ $0,029 y a n g$ berarti $p<a=0,05$ (Ho ditolak dan $\mathrm{Ha}$ diterima), maka dapat disimpulkan hubungan pengetahuan berhubungan pemeriksaan $\mathrm{Ca}$ Servik Menggunakan Metode Visual Asam Asetat (IVA) di wilayah kerja Puskesmas Hajimena Kecamatan Natar Kabupten Lampung Selatan tahun 2019, dengan nilai $\mathrm{OR} \quad 4,356(\mathrm{Cl} \quad 95 \%$ 1,318-14,391) berarti responden dengan pengetahuan yang baik memiliki peluang 4 kali lebih besar untuk melakukan pemeriksaan IVA jika dibandingkan dengan responden yang memiliki pengetahuan kurang baik.

Sejalan dengan teori Notoatmodjo (2012), pengetahuan adalah merupakan hasil dari tahu dan ini setelah orang melakukan penginderaan terhadap obyek tertentu. Penginderaan terjadi melalui panca indera manusia, yakni indera penglihatan, pendengaran, penciuman, rasa dan raba. Sebagaian besar pengetahuan manusia diperoleh melalui mata dan telinga.

Penelitian ini sejalan dengan penelitian yang dilakukan oleh Dewi (2013) dengan Hubungan Tingkat PengetahuanDan Sikap Wanita Usia Subur (WUS) Dengan Pemeriksaan Inspeksi Visual Asam Asetat (IVA) Di Puskesmas Buleleng I. Hasil penelitian ini didapatkan pengetahuan WUS $(p=0,007)$, dan secara simultan pengetahuan berpengaruh terhadap perilaku pemeriksaan IVA di Puskesmas Buleleng I. Menurut peneliti terdapat responden dengan pengetahuan tidak baik dan tidak melakukan pemeriksaan IVA sebanyak sebanyak $56(86,2 \%)$ responden, hal ini dikarenakan pengetahuan yang kurang baik tentang kanker servik dan pengetahuan tentang manfaat pemeriksaan IVA, sehingga tidak melakukan pemeriksaan IVA, sehingga hal ini sejalan dengan teori yang mengungkapkan bahwa pengetahuan akan mempengaruhi perilaku seseorang terhadap kesehatannya dimana jika seseorang berpengetahuan baik maka kemungkinana akan berperilaku kesehatan yang dapat bermanfaat bagi dirinya maupun keluarganya. Hasil uji statistik didapatkan $t$-test $>\mathrm{t}$ tabel, $13,272>1,697 p$-value $=0,000(p$-value $<a=0,05)$ yang berarti ada Pengaruh pendidikan kesehatan tentang pola makan terhadap Pengetahuan pada penderita hipertensi di Wilayah Kerja Puskesmas Rawat Inap Banjar Agung Jati Agung Kabupaten Lampung Selatan Tahun 2019.

Hasil penelitian ini sejalan dengan teori yang dikemukakan oleh Budiman (2013) bahwa pengetahuan adalah hasil dari tahu dan ini setelah orang melakukan penginderaan terhadap obyek tertentu.Penginderaan terjadi melalui panca indera manusia, yakni indera penglihatan, pendengaran, penciuman, rasa dan raba.Sebagaian besar pengetahuan manusia diperoleh melalui mata dan telinga. Pembinaan terutama di tunjukan kepada perilaku masyarakat yang sudah sehat agar tetap dipertahankan kesehatannya, artinya masyarakat yang sudah mempunyai perilaku hidup sehat (healthy life style) tetap dilanjutkan atau dipertahankan. Pengembangan perilaku sehat ini terutama ditunjukan untuk membiasakan hidup sehat bagi anak-anak. Sesuai dengan tiga faktor penyebab terbentuknya (faktor yang mempengaruhi) perilaku tersebut, maka seyogianya kegiatan pendidikan kesehatan juga ditunjukkan kepada tiga faktor berikut (Notoatmodjo, 2014).

Menurut peneliti Upaya mengubah suatu perilaku pemeliharaan yang terus menerus diperlukan suatu pendidikan kesehatan. Salah satu upaya yang bisa diberikan untuk meningkatkan kepatuhan adalah dengan memberikan pendidikan kesehatan.

Hubungan Dukungan Suami Dengan pemeriksaan Ca Servik Menggunakan Metode Visual Asam Asetat (IVA) di wilayah kerja Puskesmas Hajimena Kecamatan Natar Kabupten Lampung Selatan tahun 2019

Hasil uji statistik diperoleh $p$-value $=0,003$ yang berarti $p<a=0,05$ (Ho ditolak dan $\mathrm{Ha}$ diterima), maka dapat disimpulkan bahwa ada hubungan dukungan suami Denganpemeriksaan $\mathrm{Ca}$ Servik Menggunakan Metode Visual Asam Asetat (IVA) di wilayah kerja Puskesmas Hajimena Kecamatan Natar Kabupten Lampung Selatan tahun 2019, dengan nilai OR 6,900 (Cl 95\% 1,982 $24,021)$ berarti responden ada dukungan suami memiliki peluang 6,9 kali lebih besar untuk melakukan pemeriksaan IVA jika dibandingkan dengan responden yang tidak ada dukungan suami.

Sejalan dengan teori menurut Friedman (2014) dukungan keluarga merupakan dukungan berupa informasi verbal, sasaran, bantuan yang 
nyata atau tingkah laku yang diberikan oleh orangorang yang akrab dengan subjek didalam lingkungan sosialnya atau yang berupa kehadiran dan hal yang dapat memberikan keuntungan emosional atau pengaruh pada tingkah laku penerimaannya. Dalam hal ini orang yang merasa memperoleh dukungan sosial, secara emosional merasa lega diperhatikan, mendapat saran atau kesan yang menyenangkan pada dirinya.

Penelitian ini sejalan dengan penelitian yang dilakukan Kurniawati (2014) dengan judul Pengaruh Pengetahuan, Motivasi dan Dukungan Suami terhadap Perilaku Pemeriksaan IVA pada Wanita Usia Subur di Puskesmas Kedungrejo, diperoleh hasil penelitian ini menunjukkan bahwa ada pengaruh yang positif antara pengetahuan dengan perilaku melakukan pemeriksaan IVA dengan nilai statistic signifikan $(\mathrm{OR}=4,298 ; \mathrm{Cl} 95 \%$ 1,213 hingga15,232; $p=0.024$ ). Ada pengaruh yang signifikan antara dukungan suami dengan perilaku melakukan pemeriksaan IVA

Menurut peneliti responden yang mendapatkan dukungan dari keluarga yang baik akan lebih besar kemungkinan untuk melakukan pemeriksaan IVA. Hal ini disebabkan adanya pengaruh yang kuat dari orang terdekat atau suami akan cenderung membuat responden lebih termotivasi meningkatkan taraf kesehatannya.

Hubungan Dukungan Petugas KesehatanDengan Pemeriksaan Ca Servik Menggunakan Metode Visual Asam Asetat (IVA) Di Wilayah Kerja Puskesmas Hajimena Kecamatan Natar Kabupten Lampung Selatan Tahun 2019

Hasil uji statistik diperoleh $p$-value $=0,011$ yang berarti $p<a=0,05(\mathrm{Ho}$ ditolak dan $\mathrm{Ha}$ diterima), maka dapat disimpulkan bahwa ada hubungan dukungan petugas kesehatan Dengan Deteksi Dini Dengan Pemeriksaan Ca Servik Menggunakan Metode Visual Asam Asetat (IVA) Di Wilayah Kerja Puskesmas Hajimena Kecamatan Natar Kabupten Lampung Selatan Tahun 2019, dengan nilai $\mathrm{OR} \quad 7,438(\mathrm{Cl} \quad 95 \% \quad 1,566-35,332)$ berarti responden dengan ada dukungan peran petugas kesehatan memiliki peluang 7,4 kali lebih besar untuk melakukan pemeriksaan IVA jika dibandingkan dengan responden yang tidakada dukungan peran petugas.

Petugas kesehatan adalah seseorang yang bertanggung jawab dalam memberikan pelayanan kesehatan kepada individu, keluarga dan masyarakat. Petugas kesehatan berdasarkan pekerjaannya adalah tenaga medis, dan tenaga paramedis seperti tenaga keperawatan, tenaga kebidanan, tenaga penunjang medis dan lain sebagainya.

Penelitian ini sejalan dengan penelitian yang dilakukan olehMasturoh (2016) dengan judul Faktor Faktor yang Mempengaruhi Wanita Usia Subur (WUS) dalamMelakukan Deteksi Dini Kanker Serviks dengan Inspeksi Visual Asam Asetat(IVA) di Wilayah Kerja Puskesmas Bangetayu Kota Semarang. Hasil penelitian menunjukkan faktor yang mempengaruhi pemeriksaankanker serviks adalah dukungan petugas kesehatan $(p=0,025)$.

Menurut pendapat peneliti peran petugas kesehatan untuk menyadari bahwa pemeriksaan IVA penting bagi lbu/ WUS merupakan hal yang utama untuk meningkatkan derajat kesehatan dalam pendeteksian dini kanker servik, hal ini dapat menimbulkan perilaku positif ibu/WUS untuk melakukan pemeriksaan IVA .

\section{KESIMPULAN}

Diketahui bahwa responden yang tidak melakukan pemeriksaan IVAy aitu sebanyak 66 $(80,5 \%)$ responden. Pengetahuan kurang baik sebanyak $65(79,3 \%)$ responden. Responden yang tidak ada dukungan suami sebanyak 51 $(62,2 \%)$ responden. Responden yang mengatakan ada dukungan petugas tentang pemeriksaan IVA sebanyak $46(56,1 \%)$ responden. Ada hubungan pengetahuan dengan pemeriksaan $\mathrm{Ca}$ Servik Menggunakan Metode Visual Asam Asetat (IVA) di wilayah kerja Puskesmas Hajimena Kecamatan Natar Kabupten Lampung Selatan tahun 2019 (pvalue $=0,029$ danOR 4,356 $(\mathrm{Cl} 95 \% 1,318-$ 14,391),Ada hubungan dukungan suami dengan pemeriksaan $\mathrm{Ca}$ Servik Menggunakan Metode Visual Asam Asetat (IVA) di wilayah kerja Puskesmas Hajimena Kecamatan Natar Kabupten Lampung Selatan tahun 2019 ( $p$-value $=0,003$ dan OR 6,900(Cl 95\% 1,982- 24,021)). Ada hubungan peran petugas kesehatan dengan pemeriksaan $\mathrm{Ca}$ Servik Menggunakan Metode Visual Asam Asetat (IVA) di wilayah kerja Puskesmas Hajimena Kecamatan Natar Kabupten Lampung Selatan tahun 2019 ( $p$-value $=0,011$ dan OR 7,438 $(\mathrm{Cl}$ 95\% $1,566-35,332)$ ).

\section{SARAN}

Diharapkan manajemen Puskesmas Hajimena Kecamatan Natar Kabupten Lampung Selatan untuk dapat: Diharapkan ada program Pemeriksaan Inspeksi Visual Asam Asetatgratis dari pemerintah yang meringankan beban masyarakat, sehingga masyarakat ikut dalam pemeriksaaan. Informasi dapat diberikan dengan cara pemberian penyluhan yang disampaikan oleh pihak puskesmas 
maupun poster-poster yang dibuat dan di pasang di tempat yang mudah terbaca oleh ibu dansuami.Peningkatan pengetahuan tidak hanya diberikan kepada ibu namun juga kepadasuami. Puskesmas diharapkan untuk lebih meningkatkan penyuluhan pada WUS tentang kanker serviks, Penyuluhan ini sebagai cara memberikan informasi dan pengetahuan kepada WUS serta mengikutsertakan suami sehingga memberikan dukungan yang baik karena suami berperan penting dalam menentukan perilaku istri dalam peeriksaan IVA.

\section{DAFTARPUSTAKA}

Apriani (2012). Faktor-Faktor Yang Mempengaruhi Keikutsertaan Dalam Pemeriksaan Inspeksi Visual Asam Asetat (IVA) Di Rumah Sakit Bunda Jakarta, Tesis

Azwar, Saipunin (2012) sikap Manusia. Teori dan pengukurannya. Jakarta: Rineka Cipta

Ackerson, K. (2007).Factors Influencing Cancer Screening Practices of Underserved Women. Journal of The American Academy of Nurse Practitioners, 19(11):591-601.

Arbyn, M. (2008). Pooled Analysis Of The Accuracy Of Five Cenvical Cancer Screening Tests Assessed in Eleven Studies in Africa and India. International Journal of cancer, 23:15360.

Budiman, (2013). Kapita Selekta Kuesioner Pengetahuan. Salemba Medika: Jakarta.

Dewi, L., Made, N., Suryani, N., \& Murdani, P. (2013). Hubungan tingkat pengetahuan dan sikap Wanita Usia Subur (WUS) dengan pemeriksaan Inspeksi Visual Asam Asetat (IVA) di Puskesmas Buleleng Jurnal Magister Kedokteran Keluarga, 1(1),57-66.

Fitriana, A, (2011). Faktor-Faktor yang Berhubunga dengan Partisipasi Wanitadalam Pemeriksaan Deteksi Dini Kanker Leher Rahim di Puskesmas Kesesi Kabupaten Pekalongan Tahun 2010, Skripsi, UniversitasNegeriSemarang.

Gaol, Tiomarni Lumban. (2013). pengaruh faktor sosiodemografi, sosioekonomi dan kebutuhan terhadap perilaku masyarakat dalam pencarian pengobatan di Kecamatan Medan Kota. balitbang.pemkomedan.go.id/.pdf.p rogram studi S2 IImu Kesehatan Masyarakat Fakultas Kesehatan Masyarakat Universitas Sumatera Utara.

Gyenwali D, Jitendra Pariyar, Sharad Raj Onta, (2013), Factors Associated with Late
Diagnosis of Cenvical Cancer in Nepal,Asian Pasific Journal ofCancer Prevention, Vol 14, No 7, hlm.4373-4377.

Hastono, Suatnto Priyo. (2016). Modul analisis data . FKM UI Jakarta

Hasibuan, Malayu S.P. (2014).Manajemen Sumber Daya Manusia. Cetakan ke-11. Jakarta: PT.Bumi Aksara.

Kementrian Kesehatan RI (2013). Riset kesehatan dasar (riskesdas) 2013. Jakarta: Badan Litbangkes Depkes RI 2013

Kemenkes, RI .( 2016).Profil Kesehatan Indonesia 2015, Jakarta

Kemenkes, Rl. (2015). Buku acuan pencegahan kanker payudara dan kanker leher rahim. Direktorat jendral PP \& PL. Direktorat Pengendalian Penyakit Tidak Menular. Jakarta.

Manuaba, IBG. (2013). IImu Kebidanan, Penyakit Kandungan dan Keluarga Berencana Untuk Pendidikan Bidan. Jakarta: EGC.

Notoatmodjo, (2012).Metodologi penelitian kesehatan. Rineka Cipta: Jakarta.

Notoatmodjo, (2012).Promosi Kesehatan dan perilaku kesehatan. Rineka Cipta: Jakarta.

Notoatmodjo, (2014).IImu perilaku kesehatan. Rineka Cipta: Jakarta. Ningrum. (2012). Faktor-Faktor Yang Mempengaruhi Motivasi Ibumengikuti Deteksi Dini Kanker Serviks Melalui Metode Inspeksi Visual Asam Asetat (Iva) Di KabupatenBanyumas.

Nursalam. (2016). Manajemen Keperawatan. Jakarta: Salemba Medika Nugroho (2010). Kesehatan Wanita gender dan permasalahannya. Yogyakarta: Nuha Medika

Puspitasari. (2015). Faktor - faktor yang mempengaruhi partisipasi ibu balita ke posyandu Kencursari I Di Dukuh Tegal tandan Desa Banguntapan Kabupaten pac. unisayogya.ac.id/567/1/NASKA H\%2OPUBLIKASISKRIPSI.pdf Program Studi Bidan Pendidik Jenjang D IV Sekolah Tinggi IImu Kesehatan 'Aisyiyah Yogyakarta.

Padila (2012) buku ajar keperawatan keluarga. Jogjakarta: Nuha Medika

Ratnasari (2011). Hubungan Penyuluhan Tentang Kanker Serviks Dengan Keikutsertaan Dan Pelaksanaan Pap Smear Di Puskesmas Ambal I Kabupaten Kebumen, Tesis

Rasjidi I (2007). Epidemiologi Kanker Serviks . Indonesian Jurnal of CancerSavitri, A dkk. 
2015. Kupas Tuntas Kanker Payudara, Leher Rahim, dan Rahim. Yogyakarta: Penerbit Pustaka Baru Press.

Riyanto Agus. (2011). Aplikasi Metodologi Penelitian Kesehatan. Jakarta: NuhaMedika Saifuddin AB. (2014) .Panduan Praktis Pelayanan Kesehatan Maternal dan Neonatal. Jakarta: EGC.

Setyaningsih. (2010). Hubungan antara tingkat pengetahuan tentang Kanker Serviks dengan motivasi melakukan pemeriksaan pap smear pada ibu rumah tangga di desa gulunan Sidokerto Kecamatan Plupuh kabupaten Sragen.

Sepa. (2015). Pengaruh Penyuluhan Kanker Serviks Terhadap Minat Pemeriksaan Pap Smear Pada Ibu Usia 20-60 Tahun Di
Dusun Ngangkrik Triharjo Sleman Tahun2015.

Sugiyono. (2016). Metode Penelitian Kuantitatif Kualitatif dan $R$ \& $D$. Bandung:Alfabeta

Susilowati (2014) Pengetahuan Tentang Faktor Risiko, Perilaku Dan Deteksi DiniKanker Serviks Dengan Inspeksi Visual Asam Asetat (Iva)Pada Wanita Di Kecamatan Bogor Tengah, Kota Bogor.

Wahyuningsih T, Mulyani EY (2014). Faktor resiko terjadinya lesi praKanker Serviks melalkukan deteksi dini dengan metode iva (inspeksi visual dengan asam asetat).Forum IImiah. 11 (2):192-209.

World Health Organization (2018). Screening for cervical cancer.

http://www.who.int/cancer/dete tion/cervical 